\title{
ROUTINE SOIL TESTING TO MONITOR HEAVY METALS AND BORON
}

\author{
Cleide Aparecida de Abreu ${ }^{1 *}$; Bernardo van Raij ${ }^{1}$; Mônica Ferreira de Abreu${ }^{1}$; Antonio Paz \\ González ${ }^{2}$ \\ ${ }^{1}$ IAC - Centro de Pesquisa e Desenvolvimento em Solos e Recursos Ambientais, Av. Barão de Itapura, 1481, C.P. 28 - \\ 13001-970 - Campinas, SP - Brasil. \\ ${ }^{2}$ Universidade A Coruña. A Zapateira, s/n. 15071 A Coruña - Spain \\ *Correspoding author <cleide@iac.sp.gov.br>
}

\begin{abstract}
Microelements are an important issue in agriculture, due to their need as micronutrients for plants and also to the possibility of the build-up of toxic levels for plants and animals. Five micronutrients (B, $\mathrm{Cu}, \mathrm{Fe}, \mathrm{Mn}$, and $\mathrm{Zn}$ ) are routinely determined in soil analysis for advisory purposes. Other four elements (Cd, $\mathrm{Cr}, \mathrm{Pb}$, and $\mathrm{Ni}$ ) are considered environmentally important heavy metals in farmland soils. Thus high contents of these metals in cropland might go eventually unnoticed. In this paper we present an approach that can be used to monitor the contents of the nine elements in farmland soils using advisory soil testing. A total of 13,416 soil samples from 21 Brazilian states, 58\% of them from the state of São Paulo, sent by farmers were analyzed. Boron was determined by hot water extraction and the other metals were determined by DTPA ( $\mathrm{pH} 7.3$ ) extraction. The ranges of content, given in $\mathrm{mg} \mathrm{dm}^{-3}$ soil, were the following: $\mathrm{B}, 0.01-10.6 ; \mathrm{Cu}, 0.1-56.2 ; \mathrm{Fe}, 0.5-476$; $\mathrm{Mn}$, $1-325 ; \mathrm{Zn}, 1-453 ; \mathrm{Cd}, 0.00-3.43, \mathrm{Cr}, 0.00-42.9 ; \mathrm{Ni}, 0.00-65.1 ; \mathrm{Pb}, 0.00-63.9$. The respective average values for São Paulo were: B-0.32; Cu-2.5; Fe-36; Mn-16; Zn-4.8; Cd-0.02; Cr-0.03; Ni-0.18; Pb-0.85. For other states the results are in the same ranges. The higher values are indicative of anthropogenic inputs, either due to excess application of fertilizers or to industrial or mining activities. The conclusion is that massive chemical analysis of farmland soil samples could serve as a database for indicating potential micronutrient deficiency and excesses or heavy metal buil-up in croplands, allowing preventive actions to be taken.
\end{abstract}

Key words: soil analyses, micronutrients, heavy metals, deficiency, toxicity, interpretation limits

\section{USO DA ANÁLISE DE ROTINA PARA MONITORAR A CONCENTRAÇÃO DE METAIS PESADOS E BORO EM SOLOS}

RESUMO: Microelementos têm um papel importante na agricultura, devido à sua essencialidade para plantas e também à possibilidade de serem tóxicos às plantas e aos animais. Os cinco micronutrientes $(\mathrm{B}, \mathrm{Cu}, \mathrm{Fe}, \mathrm{Mn}, \mathrm{e}$ Zn) são comumente determinados nas análises rotineiras de solos com finalidade de recomendação de adubação. Os outros quatro elementos $(\mathrm{Cd}, \mathrm{Cr}, \mathrm{Pb}$, e $\mathrm{Ni})$ são metais pesados importantes para os solos agrícolas e não são normalmente determinados em amostras de solos enviadas pelos agricultores. Portanto, altos teores desses metais pesados em terras agricultáveis poderão passar despercebidos. O objetivo deste trabalho foi usar a análise de rotina de solo para monitorar o teor dos nove elementos em amostras de solo. Um total de 13.416 amostras de solo de 21 estados brasileiros, sendo 58\% delas originárias do estado de São Paulo, foram analisadas. O boro foi determinado usando a água quente e os outros metais foram extraídos pelo DTPA ( $\mathrm{pH} 7,3)$. Considerando todas as amostras, as faixas dos teores, em de $\mathrm{mg} \mathrm{dm}^{-3}$ foram: $\mathrm{B}, 0,01-10,6 ; \mathrm{Cu}, 0,1-56,2 ; \mathrm{Fe}, 0,5-476 ; \mathrm{Mn}, 1-325 ; \mathrm{Zn}$, 1-453; Cd 0,00-3,43, Cr, 0,0-42,9; Ni, 0,00-65,1; Pb, 0,00-63,9. Os valores médios para amostras originadas do Estado de São Paulo foram de: 0,32-B, 2,5-Cu, 36-Fe, 16,1-Mn, 4,8-Zn, 0,02-Cd, 0,03-Cr, 0,18-Ni e 0,85-Pb. Resultados semelhantes foram obtidos para amostras de outros Estados. Os valores mais altos são indicativos de ação antropogênica, devido à aplicação de fertilizantes ou de atividades industriais de mineração. Análises de rotina feitas na amostras de solos do Brasil, especialmente originárias do estado de São Paulo, podem servir com base de dados para indicar o potencial de deficiência de micronutrientes ou fitotoxicidade de metal pesado em solos agricultáveis, permitindo a tomada de ações preventivas.

Palavras-chave: análise de solo, micronutriente, deficiência, toxicidade, limites de interpretação

\section{INTRODUCTION}

Some agricultural regions in Brazil present large areas deficient in micronutrients, especially zinc and boron. On the other hand, there is also a risk of contamina- tion of soils with excess metals because of atmospheric deposition near industrial complexes, the use of urban or industrial wastes, and the use of pesticides or fertilizers that contain considerable amounts of metals. There is a growing concern about the possibility of soil contamina- 
tion resulting in uptake by plants and the introduction of the elements in vital food chains, affecting food safety. Thus knowledge of buildup of metals in soils of cultivated areas is important to recognize potential ecological problems.

To monitor contamination of soils by heavy metals, the Environmental Protection Agency of the United States (USEPA, 1993) recommends the determination of "total" contents in soils, extracted with concentrated nitric acid (Kingston \& Jassie, 1988), even if the results often do not represent a good indication of bioavailability to plants. The availability of elements for plants in an agronomic sense can be estimated with reasonable precision by soil analysis, which allows the determination of the degree of deficiency, sufficiency or excess of plant nutrients and other elements. In principle it can also be used for environmental monitoring, but the diagnosis of toxic levels of nutrients and other elements is seldom a concern in routine soil testing.

Surveys and maps showing the status of micronutrients and other elements in soils might be helpful in recognizing and understanding the nature and extent of deficiencies as well as excesses. Several alternatives have been used for the survey and mapping of the availability of micronutrients in soils for several parts of the world (Berger, 1962; Kang \& Osiname, 1985; Katyal \& Vlek, 1985; Li \& Mahler, 1992; Bradford et al., 1996). In spite of these maps or surveys being highly informative, their cost is high, mainly because of the soil sampling step. Furthermore, information about micronutrient and heavy metal contents Brazilian farmland soils are scarce. An alternative method is presented in this paper, using available data, for the evaluation of the contents of boron, micronutrients and other heavy metals, in the state of São Paulo and other states of Brazil, using soil samples sent for routine soil testing.

\section{MATERIAL AND METHODS}

\section{Soil samples}

The results presented are from 13,416 soil samples of the plow layer $(20 \mathrm{~cm}$ depth) sent to the Soil Testing Laboratory of the Instituto Agronômico de Campinas, state of São Paulo, Brazil, from 1993 to 1999. There was no control of possible samples taken on the same areas in different years. The samples are from farmers fields of 21 of the Brazilian states (SP, AC, AM, BA, CE, ES, GO, MA, MG, MT, MS, PA, PE, PR, RO, RJ, $\mathrm{RN}, \mathrm{RR}, \mathrm{SC}, \mathrm{SE}, \mathrm{TO}$ ); from these, $58.1 \%$ were from the state of São Paulo. The samples were from soils originally under forest or cerrado (a type of savannah vegetation on soils of extremely low fertility), mostly classified as oxisols, ultisols and alfisols, and cultivated with grass, sugarcane (Saccarum spp.), coffee (Coffe arabica L.), eucalyptus (Eucalyptus spp.), rubber trees (Hevea brasilienses Muell. Arg.), tea (Camellia sinensis (L.) O. Kuntze), coconut (Cocus nucifera L.), oats (Avena sativa L.), palm cabbage (Euterpe spp.), cassava (Manihot esculenta Crantz), soybean (Glycine max (L.) Merrill), corn (Zea mays L.), wheat (Triticum aestivum L.), cotton (Gossypium hirsutum L.), beans (Phaseolus vulgaris L.), peas (Pisum sativum L.), sunflower (Helianthus annuus L.), guarana (Paullinia cupana H.B.K.), 22 types of fruits (mostly citrus), ornamental plants, pastures and samples for which the plant species were not informed.

\section{Soil chemical analysis}

The soil samples were analyzed for boron using the hot-water extraction with microwave heating, as described by Abreu et al. (1994). Boron was determined by a spectrophotometric method using azomethine-H. The metals cooper, iron, manganese, zinc, cadmium, chromium and lead were extracted from soils with a DTPA solution at pH 7.3 (Lindsay \& Norvell, 1978) and determined by plasma emission spectrometry ICP). Using standard procedures of soil testing for advisory purposes, the analyses were made using scoop volume measurements of the soil samples, a convenient and accurate procedure (Raij \& Grohmann, 1989).

\section{Interpretation of limits of micronutrients and metals in soils}

The classes of low, medium and high contents were according to the recommendation for the state of São Paulo for susceptible crops (Raij et al., 1996) (Table 1). For very high level of micronutrients in soils, since interpretation criteria are not yet available, tentative contents are suggested (Table 1). The interpretation of toxic level was used according to Alloway (1995).

For the four metals $(\mathrm{Cd}, \mathrm{Cr}, \mathrm{Ni}$, and $\mathrm{Pb})$ extracted by DTPA at $\mathrm{pH}$ 7.3, official interpretation of toxic levels is not yet available for Brazilian soils. A first tentative interpretation was made to diagnose contamination by comparing the contents in agricultural soils with the values found in undisturbed control soils. For this, the maximum values obtained for the 3 rd quartile were compared with the data obtained by Cancela (2002) for several soil profiles of undisturbed soils of São Paulo state (Brazil). The interpretation values found, in $\mathrm{mg} \mathrm{dm}^{-3}$, were: $\mathrm{Cd}$, $0.08 ; \mathrm{Cr}, 0.21 ; \mathrm{Pb}, 1.15$; and, $\mathrm{Ni}, 1.85$.

A software (MICAGRI) was developed to process results of soil analysis from the soil testing laboratory of Instituto Agronômico. This software handles the analytical results of micronutrients and heavy metals and information such as farmers name, address, city, state, crop, and in some cases, fertilizers used.

A descriptive statistics for the determination of the minimum, maximum, average and median for the micronutrients and heavy metal was applied for all 13.416 soil samples, separating the results in two groups accord- 
ing to the origin: from the state of São Paulo (7.802 samples) and from other states (5.614 samples). The results were separated in quartiles, with $25 \%$ of samples with low values in the first quartile, $50 \%$ in the second and $75 \%$ in the third.

\section{RESULTS AND DISCUSSION}

\section{Boron}

The range of variation was from 0.01 to $10.6 \mathrm{mg}$ $\mathrm{dm}^{-3}$ for the state of São Paulo, with an upper value of the 3rd quartile of $0.35 \mathrm{mg} \mathrm{dm}^{-3}$ (Table 2). For the other states, the range was from 0.01 to $8.25 \mathrm{mg} \mathrm{dm}^{-3}$, with a value of 0.35 for the third quartile (Table 2). Considering that soils with less than $0.20 \mathrm{mg} \mathrm{B} \mathrm{dm}^{-3}$ are deficient for crops that are more sensitive to B deficiency, $37 \%$ of the soil samples of the state of São Paulo are in this class (Table 3), suggesting the need of fertilization with this element, especially for crops more susceptible to B deficiency. Considering low and medium values, between 0 and $0.60 \mathrm{mg} \mathrm{dm}^{-3}, 92 \%$ of the samples are included, indicating that probably the quantities of $\mathrm{B}$ applied in agriculture are rather low. The high levels of B can be damaging for crops, but are not an environmental problem in humid climates, such as the case of the state of São Paulo, because the element leaches out easily of the rooting zone.

The distribution of $\mathrm{B}$ contents in other states was similar to that of the state of São Paulo: $85 \%$ of the samples presenting values bellow $0.60 \mathrm{mg} \mathrm{dm}^{-3}$ and $43 \%$ below $0.20 \mathrm{mg} \mathrm{dm}^{-3}$ (Table 3). Considering all the soil samples analyzed, only $10 \%$ presented contents of B higher than $0.60 \mathrm{mg} \mathrm{dm}^{-3}$. Most samples came from areas cultivated with coffee (Coffe arabica L.), grapes (Vitis

Table 1 - Interpretation limits of micronutrients in soils.

\begin{tabular}{lccccc}
\hline Soil content & \multicolumn{2}{c}{ Hot water } & & \multicolumn{2}{c}{ DTPA pH 7.3 } \\
\cline { 2 - 3 } \cline { 5 - 6 } & $\mathrm{B}$ & $\mathrm{Cu}$ & $\mathrm{Fe}$ & $\mathrm{Mn}$ & $\mathrm{Zn}$ \\
\hline Low $^{1}$ & $0.00-0.20$ & $0.0-0.2$ & $0-4$ & $0.0-1.2$ & $0.0-0.5$ \\
Medium $^{1}$ & $0.21-0.60$ & $0.3-0.8$ & $5-12$ & $1.3-5.0$ & $0.6-1.2$ \\
High $^{1}$ & $0.61-1.10$ & $0.9-1.5$ & $13-24$ & $5.1-9$ & $1.3-2.3$ \\
Very high $^{2}$ & $1.2-3.0$ & $1.6-15$ & $25-60$ & $10-50$ & $2.4-15$ \\
Toxicity $^{3}$ & $>3.0$ & & & mg dm & $>130$ \\
\hline
\end{tabular}

${ }^{1}$ Raij et al. (1996). ${ }^{2}$ Suggestion of the authors of this paper. ${ }^{3}$ Alloway (1995).

Table 2 - Descriptive statistics of the results of micronutrients in the soils of São Paulo state and from other states, analyzed in the soil testing laboratory of Instituto Agronômico.

\begin{tabular}{|c|c|c|c|c|c|}
\hline & B & $\mathrm{Cu}$ & $\mathrm{Fe}$ & $\mathrm{Mn}$ & $\mathrm{Zn}$ \\
\hline & \multicolumn{5}{|c|}{ - São Paulo state $(\mathrm{N}=7,802), \mathrm{mg} \mathrm{dm}^{3}-$} \\
\hline Minimum & 0.01 & 0.1 & 0.6 & 0.1 & 0.1 \\
\hline Maximum & 10.6 & 106 & 476 & 325 & 453 \\
\hline Average & 0.32 & 2.5 & 36 & 16.1 & 4.8 \\
\hline Median & 0.23 & 1.4 & 25 & 8.8 & 1.6 \\
\hline SD & 0.40 & 3.7 & 38.4 & 20.8 & 16.3 \\
\hline $1^{\text {st }}$ quartile & 0.16 & 0.61 & 15.7 & 3.5 & 0.7 \\
\hline $3^{\text {rd }}$ quartile & 0.35 & 3.2 & 41.0 & 21.5 & 3.6 \\
\hline \multirow[t]{2}{*}{ 95\% C.I. average } & $0.31-0.33$ & $2.4-2.6$ & $35-37$ & $15.7-16.6$ & $4.4-5.1$ \\
\hline & \multicolumn{5}{|c|}{ - } \\
\hline Minimum & 0.01 & 0.1 & 0.6 & 0.1 & 0.1 \\
\hline Maximum & 8.25 & 56.2 & 476 & 315 & 453 \\
\hline Average & 0.31 & 2.3 & 34 & 14.9 & 4.4 \\
\hline Median & 0.24 & 1.3 & 24 & 8.3 & 1.6 \\
\hline ST dev & 0.35 & 3.06 & 34.9 & 19.2 & 14.5 \\
\hline $1^{\text {st }}$ quartil & 0.17 & 0.56 & 15 & 3.3 & 0.7 \\
\hline $3^{\text {rd }}$ quartil & 0.35 & 3.1 & 39 & 19.5 & 3.7 \\
\hline $95 \%$ C. I. average & $0.31-0.32$ & $2.3-2.4$ & $33-35$ & $14.4-15.4$ & $4.0-4.8$ \\
\hline
\end{tabular}

Sci. Agric. (Piracicaba, Braz.), v.62, n.6, p.564-571, Nov./Dec. 2005 
Table 3 - Percentage (\%) of occurrence of micronutrients contents in soils according to different classes of interpretation in relation to the total samples in each region.

\begin{tabular}{|c|c|c|c|c|}
\hline Micronutrient & Low & Medium & High & Very high \\
\hline \multicolumn{5}{|c|}{--.--- São Paulo state ---.-- } \\
\hline Boron & 37 & 55 & 6 & 2 \\
\hline Copper & 7 & 26 & 21 & 46 \\
\hline Iron & 1 & 16 & 30 & 53 \\
\hline Manganese & 8 & 26 & 16 & 50 \\
\hline Zinc & 20 & 21 & 51 & 8 \\
\hline \multicolumn{5}{|c|}{ - Other states -...-...- } \\
\hline Boron & 43 & 42 & 10 & 5 \\
\hline Copper & 16 & 26 & 18 & 40 \\
\hline Iron & 1 & 12 & 27 & 60 \\
\hline Manganese & 24 & 27 & 11 & 38 \\
\hline Zinc & 33 & 20 & 16 & 31 \\
\hline
\end{tabular}

spp.), citrus (Citrus spp.) and cotton (Gossypium hirsutum L.). These crops are very responsive to boron and for this reason fertilization with this micronutrient is a common practice. For these cases, soil analysis is an important tool to assess the nutrient need considering that excess can reduce yields. In this respect, values found above $3.0 \mathrm{mg}$ $\mathrm{dm}^{-3}$ are a warning that excess applications have been ocurring.

\section{Copper}

The range of values was from 0.1 to $106 \mathrm{mg} \mathrm{dm}^{-3}$ soil for São Paulo state and from 0.1 to $56.2 \mathrm{mg} \mathrm{dm}^{-3}$ soil for the other regions. The higher limit of the 3rd quartile was $3.2 \mathrm{mg} \mathrm{dm}^{-3}$ for São Paulo and $3.1 \mathrm{mg} \mathrm{dm}^{-3}$ for the other places (Table 2), indicating a rather low range for most of the samples. Only 7\% of the samples from São Paulo and $16 \%$ from other states presented values lower than $0.2 \mathrm{mg} \mathrm{Cu} \mathrm{dm}^{-3}$, falling under the condition of high probability of copper deficiency for demanding crops and thus the need of application of the nutrient in fertilization (Table 3).

Most of the samples (46\% for São Paulo and $40 \%$ of other states) presented very high values, above $1.5 \mathrm{mg}$ $\mathrm{dm}^{-3}$ (Table 3) and this deserves extra attention. From these, 12 soil samples presented copper contents above $50 \mathrm{mg} \mathrm{dm}^{-3}$, considered toxic (Macnicol \& Beckett, 1985). The accumulation of this element in soils is probably due to spraying with copper-based pesticides. The samples came from areas cultivated with coffee, citrus, and grape crops, constantly receiving application of such products. The results suggest the need to monitor areas by regular sampling and soil analysis, to avoid the buildup of toxic levels of copper in the soil. As an example of such possibility, concentrations higher than the reference value of $30 \mathrm{mg} \mathrm{kg}^{-1}$ in plants were observed for raddish $(36.2 \mathrm{mg}$ $\left.\mathrm{kg}^{-3}\right)$ cultivated in soils containing $86 \mathrm{mg} \mathrm{dm}^{-3}$ of $\mathrm{Cu}$ extracted by $0.025 \mathrm{~mol} \mathrm{~L}^{-1}$ NaEDTA (Podlesáková et al., 2001).

\section{Iron}

The range of values of iron in soil was similar for the soils samples from the state of São Paulo and from other places, from 0.6 to $476 \mathrm{mg} \mathrm{dm}^{-3}$ (Table 2).

Only $1 \%$ of the soils of São Paulo state presented values of iron considered low, below $4 \mathrm{mg} \mathrm{dm}^{-3}$ (Table 3). A similar observation was made for samples from other states (1\%). Medium contents of iron, considered adequate for most crops, were found in $16 \%$ of the soil samples for São Paulo and 12\% for the other states. Most samples from São Paulo (53\%) and from the other states $(60 \%)$ presented iron contents higher than $24 \mathrm{mg} \mathrm{dm}^{-3}$ (Table 3). This is consistent with the high iron content of the highly weathered soils of the humid tropical climate of Brazil. The high Fe contents are also consistent with the general lack of response of plants to iron observed in greenhouse and field experiments. On the other hand, values in soils above $100 \mathrm{mg} \mathrm{Fe} \mathrm{dm}{ }^{-3}$ (around $5 \%$ of the soil samples), associated with conditions of low potassium and phosphorus status and poor drainage, can occasionally present problems of iron toxicity to crops.

\section{Manganese}

The range of manganese in the soil samples of São Paulo state was from 0.1 to $325 \mathrm{mg} \mathrm{dm}^{-3}$ and from 0.1 to $315 \mathrm{mg} \mathrm{dm}^{-3}$ for other states (Table 2). The upper limit of the third quartile was of $21.5 \mathrm{mg} \mathrm{dm}^{-3}$ for São Paulo and $19.5 \mathrm{mg} \mathrm{dm}^{-3}$ for other places (Table 2), indicating high contents of manganese for most of the samples.

If soil samples with values below $1.2 \mathrm{mg} \mathrm{dm}^{-3}$ are considered deficient, respectively $8 \%$ and $24 \%$ of the soil samples of São Paulo and from other states are included in this class (Table 3). Manganese deficient soil samples have been observed especially in the states of Mato Grosso do Sul, Paraná, Goiás and São Paulo. These data corroborate field observations indicating increasing deficiency of manganese for soybeans (Glycine max L.), often associated with poor incorporation of limestone (Novais et al., 1989). The soil samples presenting medium values $\left(1.3\right.$ to $5.0 \mathrm{mg} \mathrm{dm}^{-3}$ ) corresponded to $26 \%$ in São Paulo and $27 \%$ in the other states (Table 3). These soil samples were from areas cultivated with coffee, soybeans, beans, lowland rice, sugarcane, and some vegetable crops. This indicates the need to include manganese in the fertilization for crops that are sensitive to manganese deficiency and of the importance to monitor the availability of the nutrient by soil testing.

Most samples (50\% for São Paulo and 38\% of other states) presented very high values, higher than 9.0 $\mathrm{mg} \mathrm{dm}^{-3}$ (Table 3), that also deserve attention. Manganese 
toxicity is quite common for several crops, being associated with high acidity and poor soil aeration, a condition that occurs during periods of high rainfall or in poorly drained spots in the field.

\section{Zinc}

The range of values was from 0.1 to $453 \mathrm{mg} \mathrm{dm}^{-3}$ for São Paulo state and for the other regions (Table 2). The higher limit of the $3 \mathrm{rd}$ quartile was $3.6 \mathrm{mg} \mathrm{dm}^{-3}$ for São Paulo and $3.7 \mathrm{mg} \mathrm{dm}^{-3}$ for the other places (Table 2), indicating a rather low range for most samples.

Zinc deficiency as indicated by soil analysis is a widespread problem in Brazilian soils (Lopes, 1983). Interpretation limits for available zinc suggest that soils with less than $0.6 \mathrm{mg} \mathrm{dm}^{-3}$ are deficient. Using this limit, $20 \%$ of the soil samples from São Paulo and 33\% from other states can be classified as deficient (Table 3). The highest proportion of soil samples deficient in zinc came from the cerrado region. For crops more sensitive to zinc deficiency, responses to the element can occur in soils with medium values, from 0.6 to $1.2 \mathrm{mg} \mathrm{dm}^{-3}$. In this situation, $41 \%$ of the samples of São Paulo and $53 \%$ of the samples of other states are included. Another important point is that these soil samples represent a large range of different crops. These results are in agreement with field observations of frequent responses to zinc fertilization for different crops and localities. The upper limit is quite high
(Table 2). Samples originated from Juazeiro (BA), Petrolina (PE) and some regions of São Paulo, especially those from areas cultivated with mangos (Mangifera indica L.), citrus (Citrus sp.), and grapes (Vitis spp.), and formerly cultivated with vegetables, presented contents up to $80 \mathrm{mg} \mathrm{Zn} \mathrm{dm}^{3}$, indicating a probable overfertilization with the element. Although toxicities have not been reported for these places, this might be because of the lack of threshold criteria to identify possible negative effects of excess $\mathrm{Zn}$. Action to prevent further increases of $\mathrm{Zn}$ in soil seems appropriate. Soil samples $(2 \%)$ with contents higher than $130 \mathrm{mg} \mathrm{dm}^{-3}$, considered toxic by Alloway (1995), came from areas which had received high rates of municipal sewage sludge or other waste materials.

\section{Heavy metals (Cd, $\mathrm{Cr}$, Ni, and $\mathrm{Pb}$ )}

The range of variation of the DTPA extractable $\mathrm{Cd}, \mathrm{Cr}, \mathrm{Ni}$, and $\mathrm{Pb}$ from soils considered potentially available to plants was largest for the samples from São Paulo state (Table 4). Most samples presented very low values, but some obvious unusually high values indicate some degree of contamination.

Although the proportion of soil samples that presented high contents of heavy metals is low, with the exception of lead, the data indicate an uncommon accumulation for some agricultural soils and are indicative of anthropogenic input (Table 5).

Table 4 - Descriptive statistics of heavy metals contents in soil samples from the state of São Paulo, analyzed in the soil testing laboratory of Instituto Agronômico.

\begin{tabular}{|c|c|c|c|c|}
\hline & $\mathrm{Cd}$ & $\mathrm{Cr}$ & $\mathrm{Ni}$ & $\mathrm{Pb}$ \\
\hline & \multicolumn{4}{|c|}{ São Paulo state $(\mathrm{N}=8,702), \mathrm{mg} \mathrm{dm}^{3}$} \\
\hline Minimum & 0.00 & 0.00 & 0.00 & 0.00 \\
\hline Maximum & 3.4 & 42.9 & 65.1 & 63.9 \\
\hline Average & 0.02 & 0.03 & 0.18 & 0.85 \\
\hline Median & 0.01 & 0.01 & 0.10 & 0.58 \\
\hline $\mathrm{SD}$ & 0.06 & 0.81 & 1.18 & 1.81 \\
\hline $1^{\text {st }}$ quartile & 0.01 & 0.00 & 0.05 & 0.30 \\
\hline $3^{\text {rd }}$ quartile & 0.02 & 0.01 & 0.19 & 1.00 \\
\hline \multirow[t]{2}{*}{$95 \%$ C. I. average } & $0.019-0.022$ & $0.01-0.05$ & $0.16-0.21$ & $0.81-0.89$ \\
\hline & \multicolumn{4}{|c|}{ Other states $(\mathrm{N}=5,614), \mathrm{mg} \mathrm{dm}^{-3}$} \\
\hline Minimum & 0.00 & 0.00 & 0.00 & 0.00 \\
\hline Maximum & 1.31 & 0.80 & 2.00 & 33.89 \\
\hline Average & 0.019 & 0.007 & 0.147 & 0.76 \\
\hline Median & 0.01 & 0.00 & 0.10 & 0.51 \\
\hline SD & 0.04 & 0.02 & 0.17 & 1.24 \\
\hline $1^{\text {st }}$ quartile & 0.01 & 0.00 & 0.05 & 0.29 \\
\hline $3^{\text {rd }}$ quartile & 0.02 & 0.01 & 0.02 & 0.90 \\
\hline $95 \%$ C. I. average & $0.018-0.020$ & $0.006-0.007$ & $0.142-0.151$ & $0.733-0.798$ \\
\hline
\end{tabular}

Zeroed values do not mean necessarily the absence of the element in the sample, but primarily indicate readings lower than the dectection limit of the ICP-OES or lower of the overall determination error. 
The proportion of samples that presented contents higher than those found in uncultivated soils was $2.3 \%$ for $\mathrm{Cd}, 0.4 \%$ for $\mathrm{Cr}, 0.2 \%$ for $\mathrm{Ni}$, and $20 \%$ for $\mathrm{Pb}$ (Table 5 ). These results also suggest that the long term applications of ammendments and mineral fertilizers, largely used in agriculture, are not affecting significantly the heavy metal contents in soils and that probably the transfer of metals to the food chain is small in most cases. However, the few cases of higher contents should receive extra attention. Most of these samples with high contents of heavy metals $(\mathrm{Cd}, \mathrm{Cr}$, and $\mathrm{Ni})$ came from areas that had received high rates of sewage sludge, widely known as a major source of heavy metals. However, soils with high lead contents are more widespread, occurring in areas with diverse land use cultivated with coffee, citrus, vegetables and pasture.

The anthropogenic sources of heavy metals include atmospheric deposition in the vicinity of industrial regions, the use of urban and agroindustrial residues, the use of pesticides and of some fertilizers containing higher concentrations of heavy metals. Depending on the source, high contents of heavy metals might appear in certain sites, as episodic contamination, and non-point or difuse of contamination is not expected. In this research the higher contents found for a small part of the samples indicate a probable origin of non-agricultural sources, but nevertheless important. Activities that can cause contamination of soil and plant in general can cause important effects in the long run. Due to the often irreversible nature and gravity of the problems, it is necessary to use all knowledge available for prevention, as is the case of the method proposed in this paper.
The numerical criteria used to delineate contaminated soils is generic in nature and cannot delineate categories by soil type, land use, or input source, and are only a tentative reference for preliminary evaluation and diagnosis of specific situations of soil contamination. According to the results (Table 6), the number of samples contaminated is small. Even so, the specific cases in which the elements are present in high concentrations, with risk of reaching the food chain, deserve attention. Plants might absorb these elements depending on their availability and the degree of transfer from soil to plant, which varies for the different elements, soil type, crop species and cultivars, etc. Cadmium is of particular concern because of its high proportion in plant available form in the soils and its possible accumulation to potentially harmful levels for humans in the food chain (Han et al., 2001). In this respect, cadmium differs markedly from lead in that it is transported readily from the soil via the plant root to the upper plant parts whereas lead is not (Marschner, 1986).

In some situations, the plants might not be affected, but the elements might affect humans and animals that use the plants as food or feed, especially if they are cumulative in the organisms. For example, plants can be quite healthy but contain concentrations of $\mathrm{Cd}$ that are too high and unacceptable in an animal or human diet (McLaughlin et al., 2000). Cases of metal contaminations are known all over the world, as is the case of high $\mathrm{Cd}$ in lowland rice grains cultivated near mining areas (Kobayashi, 1978) and of $\mathrm{Pb}$ for low income populations in Latin America living close to industrial areas (Tong et al., 2000).

Table 5 - Comparison of heavy metals contents found in the soil samples analyzed by the Soil Testing Laboratory of Instituto Agronômico and the maximum contents found in undisturbed soil profiles in the state of São Paulo according to Cancela et al. (2002).

\begin{tabular}{lcccc}
\hline & $\mathrm{Cd}$ & $\mathrm{Cr}$ & $\mathrm{Ni}$ & $\mathrm{Pb}$ \\
\hline${ }^{1}$ Maximum content in undisturbed soils, $\mathrm{mg} \mathrm{dm}{ }^{-3}$ & 0.08 & 0.21 & 1.85 & 1.2 \\
Samples with contents above the undisturbed soils, \% & 2.29 & 0.35 & 0.19 & 19.6 \\
\hline
\end{tabular}

${ }^{1}$ Cancela et al. (2002)

Table 6 - Higher values of $\mathrm{Cd}, \mathrm{Cr}, \mathrm{Ni}$, and Pb extracted by DTPA pH 7.3 in soil samples sent to the Soil Testing Laboratory of the Institute of Agronomy.

\begin{tabular}{|c|c|c|c|}
\hline \multirow[t]{3}{*}{ Heavy metal } & \multirow{2}{*}{$\frac{\text { Reference value }^{1}}{\mathrm{mg} \mathrm{kg}^{-1}}$} & \multicolumn{2}{|c|}{$\begin{array}{l}\text { Metal contents found in soil samples with contents higher than the } \\
\text { reference values, with the exception of lead }\end{array}$} \\
\hline & & - & 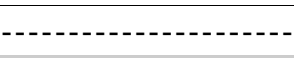 \\
\hline & & São Paulo state & Other states \\
\hline $\mathrm{Cd}$ & 3 & 3.4 & 3.4 \\
\hline $\mathrm{Cr}$ & 25 & $28.5,30.7,39.0,42.9$ & --- \\
\hline $\mathrm{Ni}$ & 20 & $25.9,31.4,33.5,39.9,40.3,65.1$ & 34.8 \\
\hline $\mathrm{Pb}$ & 600 & $26,27,34,46,59,59,64$ & 26,38 \\
\hline
\end{tabular}

${ }^{1} \mathrm{Cd}$ and $\mathrm{Ni}$ extracted by $0.05 \mathrm{~mol} \mathrm{~L}^{-1}$ EDTA; $\mathrm{Cr}^{+6}$ by $0.1 \mathrm{~mol} \mathrm{~L}^{-1} \mathrm{HCl}$; Alloway (1995)

Sci. Agric. (Piracicaba, Braz.), v.62, n.6, p.564-571, Nov./Dec. 2005 
Table 7 - Comparisons of the DTPA extractable contents found in Brazilian soils with the limits of maximum total contents suggested by Alloway (1995), and by Kabatia Pendias and Pendias (1992).

\begin{tabular}{|c|c|c|c|c|c|}
\hline Element & $\begin{array}{l}\text { Brazil, São Paulo } \\
\text { state }\end{array}$ & $\begin{array}{l}\text { Brazil, other } \\
\text { states }\end{array}$ & $\begin{array}{l}\text { USA Alloway } \\
\text { (1995) }\end{array}$ & $\begin{array}{c}\text { European } \\
\text { UnionAlloway (1995) }\end{array}$ & $\begin{array}{l}\text { Kabatia-Pendias and } \\
\text { Pendias (1992) }\end{array}$ \\
\hline & \multicolumn{2}{|c|}{------- DTPA, mg dm ${ }^{-3}$} & 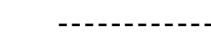 & $\cdots-$ TOTAL, mg kg & - \\
\hline $\mathrm{Cu}$ & 50-106 (5)1 & $50-56(1)$ & 750 & $50-140$ & $60-125$ \\
\hline $\mathrm{Zn}$ & $150-452 \quad(20)$ & $70-452 \quad(13)$ & 1400 & $150-300$ & $700-400$ \\
\hline $\mathrm{Cd}$ & $1-3 \quad(4)$ & $1-3 \quad(2)$ & 20 & $1-3$ & $3-8$ \\
\hline $\mathrm{Cr}$ & $100 \quad(0)$ & $100(0)$ & 1500 & $100-150$ & $75-100$ \\
\hline $\mathrm{Ni}$ & $30-65 \quad(5)$ & $30 \quad(0)$ & 210 & $30-75$ & 100 \\
\hline $\mathrm{Pb}$ & $50-64 \quad(3)$ & $50(0)$ & 150 & $50-300$ & $100-400$ \\
\hline
\end{tabular}

in parenthesis number of samples.

In Brazil, in 1994 the press made public the existence of high $\mathrm{Pb}$ contents in milk and in the blood of children in the region of Caçapava, São Paulo (Abreu et al., 1998). Such cases reinforce the importance of monitoring and knowing the levels of non-nutrient potentially toxic metals in soils and plants, to prevent the transfer of these metals to the food chain in contaminated areas.

According to Podlesáková et al. (2001) Ni concentration in plants above the reference value $\left(5 \mathrm{mg} \mathrm{kg}^{-1}\right)$ was observed in raddish $\left(8 \mathrm{mg} \mathrm{kg}^{-1}\right)$ growing in soils with $\mathrm{pH}$ 4.8 and with $15 \mathrm{mg} \mathrm{kg}^{-1}$ EDTA extractable Ni. For $\mathrm{Pb}$, only in soils with pH 4.8 and EDTA extractable contents of $844 \mathrm{mg} \mathrm{kg}^{-1}$, plant concentrations above the reference value of $10 \mathrm{mg} \mathrm{kg}^{-1}$ were found. The values were $39 \mathrm{mg}$ $\mathrm{kg}^{-1}$ in raddish and $12 \mathrm{mg} \mathrm{kg}^{-1}$ in triticale. For Cr, the authors found $13 \mathrm{mg} \mathrm{kg}^{-1}$ in radish and $8 \mathrm{mg} \mathrm{kg}^{-1}$ in triticale, which are above the reference values of 4 to $5 \mathrm{mg}$ $\mathrm{kg}^{-1}$. The plants were cultivated in soils with $13 \mathrm{mg} \mathrm{dm}$ of EDTA extractable $\mathrm{Cr}$.

\section{Comparison of heavy metal contents in soils and al- lowable limits}

A comparison was made of the results found in this research and the maximum allowable values indicated by Alloway (1995) and by Kabata Pendias \& Pendias (1992) (Table 7). For the results of this paper, the range given considered the minimum values given by the $\mathrm{Eu}-$ ropean Union. Iron and manganese pose no environmental problems and for this reason were not included. The results of DTPA extractions will always be lower than the limits given in these three sources, which are total contents. Even so, there are values of DTPA extractable zinc above the limits accepted in Europe, and $\mathrm{Cd}$ and Ni contents were close.

The fact that the metal contents of soil samples with higher values of the four heavy metals were far above the "normal" contents, as can be concluded comparing the results of Tables 6 and 7 with Tables 4 and 5, indicates that the DTPA extraction is an adequate tool for the identification of important soil contamination with the metals. In addition, total contents will be certainly higher than the figures given for DTPA.

The methods proposed, relying on results of available results of routine soil testing, can give an immediate appraisal of the micronutrients and the nonnutrientes microlements of the soil samples from farmers fields. If excessive contents are found, action can be taken to propose solutions or to investigate the origin of the excessive values. Although the exact location is some times difficult to access, in most case the farmers questionnaire will allow to locate at leat the farm location. It should also be pointed out that the method proposed has at the moment no better alternative that is feasible.

\section{CONCLUSION}

The method of DTPA used for the determination of $\mathrm{Cu}, \mathrm{Mn}, \mathrm{Fe}$ and $\mathrm{Zn}$ in soil samples from farmers can be used for the determination of $\mathrm{Cd}, \mathrm{Cr}, \mathrm{Ni}$ and $\mathrm{Pb}$ with little extra cost, allowing the identification of contaminated soils of farmersd fields.

\section{ACKNOWLEDGMENTS}

This project was supported in part by FAPESP. C.A., Abreu and M.F., Abreu, would also like to acknowledge $\mathrm{CNPq}$ for research fellowships.

\section{REFERENCES}

ABREU, C.A.; ABREU, M.F.; ANDRADE, J.C. Distribuição de chumbo no perfil de solo avaliado pelas soluções de DTPA e Melich-3. Bragantia, v.57, p.185-192, 1998.

ABREU, C.A.; ABREU, M.F.; RAIJ, B.van; ANDRADE, J.C. The extraction of boron from soil by microwave heating for ICP-AES determination. Communications in Soil Science and Plant Analysis, v.25, p.33213333, 1994.

ALLOWAY, B.J. Heavy metals in soils. London: Blackie Academic \& Professional, 1995. 368p.

BERGER, K.C. Micronutrient deficiences in the United States. Palo Alto: Agriculture Food Chemistry, 1962. cap.10, p.178-181. 
BRADFORD, G.R.; CHANG, A.C.; PAGE, A.L.; FRAMPTON, J.A.; WRIGHT, H. Background concentrations of trace and major elements in California soils. Berkeley: Kearncy Foundation of Soil Science, Division of Agriculture and Natural, 1996.

CANCELA, R. Contenido de macronutrientes, micronutrientes, metales pesados y otros elementos in suelos naturales de São Paulo (Brasil) y Galicia (España). Coruña: Universidad de La Coruña, 2002. 574p. (Tesis - Doctoral).

HAN, F.X.; KINGERY, W.L.; SELIM, H.M. Accumulation, redistribution, transport and bioavailability of heavy metals in waste-amended soils. In: ISKANDAR, I.K.; KIRKHAM, M.B. (Ed.) Trace elements in soil, flux and transfer. Boca Raton: Lewis Publishers, 2001.

KABATIA-PENDIAS, A.; PENDIAS, H. Trace elements in soil and plants. 2.ed. Boca Raton: CRC Press, 1992. 315p.

KANG, B.T.; OSINAME, O.A. Micronutrient problems in tropical Africa. Fertilizer Research, v.7, p.131-150, 1985.

KATYAL, J.C.; VLEK, P.L.G. Use of cluster analysis for classification of benchmark soil samples from India in diferrent micronutrient availability groups. Journal of Agricultural Science, v.104, p.421-424, 1985.

KINGSTON, H.M.; JASSIE, L.B. Safety guidelines for microwave systems on the analytical laboratory. In: KINGSTON, H.M.; JASSIE, L.B. (Ed.) Introduction to microwave acid decomposition: theory and practice. Washington: ACS, 1988. (Professional Reference Book Series).

KOBAYASHI, J. Pollution by cadmium and the itai-itaidisease in Japan. In: OEHME, F.W. Toxicity o heavy metals in the environment. New York: Marcel Dekker, 1978.

LI, G.R.; MAHLER, R.J. Micronutrients in the Kootenai River Valley of northern Idaho. Effect of soil chemical properties on micronutrient availability. Communications in Soil Science and Plant Analysis, v.23, p.1161-1178, 1992

LINDSAY, W.L.; NORVELL, W.A. Development of a DTPA soil test for zinc, iron, manganese and copper. Soil Science Society of America Journal, v.42, p.421-428, 1978.
LOPES, A.S. Solos sob cerrado. Piracicaba: Instituto da Potassa \& Fosfato, 1983. 162p.

McLAUGHLIN, M.J.; ZARCINAS, B.A.; STEVENS, D.P.; COOK, N. Soil Testing for heavy metals. Communications in Soil Science and Plant Analysis, v.31, p.1661-1700, 2000.

MACNICOL. R.D.; BECKETT, P.H.T. Critical tissue concentrations of potentially toxic elements. Plant and Soil, v.85, p.107-129, 1985.

MARSCHNER, H. Mineral nutrition of higher plants. London: Academic Press, 1986. 674p.

NOVAIS, R.F.; NEVES, J.C.L.; BARROS, N.F.; SEDIYAMA, T. Deficiência de manganês em plantas de soja cultivadas em solos de cerrado. Revista Brasileira de Ciência do Solo, v.13, p.199-204, 1989.

PODLESÁKOVÁ, E.; NEMECCEK, J.; VÁCHA, R. Mobility and bioavailability of trace elements in soils. In: ISKANDAR, I.K.; KIRKHAM, M.B. (Ed.) Trace elements in soil bioavailability, flux and transfer. London: Lewis Publishers, 2001. p.21-42.

RAIJ, B.van; QUAGGIO, J.A.; CANTARELLA, H.; ABREU, C.A. Interpretação dos resultados de análise de solo. In: RAIJ, B.van; CANTARELlA, H.; QUAGGIO, J.A.; FURLANI, A.C. (Ed.) Recomendações de adubação e calagem para o estado de São Paulo. 2.ed. Campinas: Instituto Agronômico; Fundação IAC, 1996. p.8-13. (Boletim Técnico).

RAIJ, B. van; GROHMANN, F. Densidade global de solos medida com anel volumétrico e por cahimbagem de terra fina seca ao ar. Brangantia, v.48, p.125-130, 1989.

US ENVIRONMENTAL PROTECTION AGENCY. Standards for the use or disposal of sewage sludge. Federal Register, v.58, p.210-247, 1993

TONG, S.; SCHIRNDING, Y.E.; PRAPAMONTOL, T. Environmental lead exposure: a public health problem of global dimensions. Bulletin of the World Health, v.79, p.1068-1077, 2000.

Received October 15, 2004

Accepted November 04, 2005 